\title{
Komunikasi Organisasi Pemimpin Dalam Membangun Kineja Aparatur di IAIN Pekalongan Tahun 2019-2020
}

\author{
Edy Zubaidi \\ Institut Agama Islam Negeri Pekalongan \\ Edyzubaidi76@gmail.com \\ Mukoyimah \\ Institut Agama Islam Negeri Pekalongan \\ mukoyimah@iainpekalongan.ac.id
}

\begin{abstract}
The purpose of this research is to find out how much influence the leader communication has to the apparaturs in realizing the mission of the institution in LAIN Pekalongan. The method used is a qualitative field with a case study approach. The case study that the author is doing is intrinsic, the research will focus on organizational communication activities carried out by the leader to the apparatus in the IAIN Pekalongan environment. While data collection using sampling with data analysis study is bolistic. Holistic analysis is needed by the writer to describe in detail the communications, the context of the communication, and the setting in which the communication takes place. The result of this research is that organizational communication is carried out on the principles of kinship and culture. This concept encourages the realization of harmonious conditions in the staffing environment of IAIN Pekalongan. Cultural principles are realized in the form of Asah, Asih, and Asub between the leadership and the apparatus under them. These three principles appear in every formal and non-formal activity, including workshops, Trining, FGD, seminars, istighosah, autbond, dies natalis, and others. Meanwhile, the family principle is realized in daily interactions both in the office and outside the office. Organizational communication by the leader to the apparatus in the IAIN Pekalongan environment is able to encourage the realization of the institution's Vision and Mission.
\end{abstract}

Keyword: Organizational Communication, Performance, and Apparatus.

\begin{abstract}
Abstrak
Tujuan penilitian ialah untuk mengetahui seberapa besar pengaruh komunikasi pemimpin kepada aparatur dalam mewujudkan misi institusi di lingkungan IAIN Pekalongan. Metode yang digunakan ialah kualitatif lapangan dengan pendekatan studi kasus. Studi kasus yang penulis lakukan ialah intrinsik, penelitian akan fokus pada kegiatan komunikasi organisasi yang dilakukan oleh pemimpin kepada aparatur dilingkungan IAIN Pekalongan. Sedangakn pengumpulan data menggunakan sampling dengan studi analisis datanya ialah holistik. Analisis holistik diperlukan penulis untuk mendiskripsikan secara detail komunikasi-komunikasi, konteks komunikasi,
\end{abstract}


dan setting di mana komunikasi itu dilakukan. Adapun hasil dari penelitian ini ialah komunikasi organisasi terlaksana atas prinsik kekeluargaan dan kebudayaan. Konsep ini mendorong terwujudnya kondisi harmonis dalam lingkungan kepegawaian IAIN Pekalongan. Prinsip kebudayaan terealisasi dalam bentuk Asah, Asih, dan Asuh antara pimpinan kepada aparatur di bawahnya. Ketiga prinsip ini nampak disetiap kegiatan-kegiatan formal maupun non formal, diantaranya workshop, Trining, FGD, seminar, istighosah, autbond, dies natalis, dan lainnya. Sedangkan prinsip kekeluargaan terealisasi dalam interaksi sehari-hari baik dalam kantor maupun diluar kantor. Komunikasi organisiasai oleh pemimpin kepada aparaturnya dilingkungan IAIN Pekalongan mampu mendorong terealisasikan Visi Misi institusi.

Kata kunci: Komunikasi Organisasi, Kinerja, dan Aparatur.

\section{Pendahuluan}

Perguruan Tinggi memiliki peran strategis dalam pengembangan SDM (Sumber Daya Manusia) di masa mendatang. Kualitas generasi di masa yang mendatang akan menentukkan keberhasilan bangsa ini dalam bersaing di dunia global. Tantangan inilah yang menjadikan perguruan tinggi dituntut untuk bekerja profesional dengan mengedepankan kualitas dan mutu para lulusan agar mampu bersaing dan siap menghadapai dunia profesi. Meski tantangan yang dihadapi perguruan tinggi tidak mudah, namun dalam catatan kurun waktu 5 tahun terakhir Perguruan Tinggi Keagamaan Islam (PTKI) telah mengalami berbagai perubahan.

Perubahan Perguruan Tinggi Keagamaan Islam (PTKI) diantaranya dari aspek regulasi, misalnya PTKI dibawah naungan Kemenag RI kini banyak yang telah berubah statusnya dari Sekolah Tinggi (ST) menjadi Institut dan dari Institut menjadi Universitas. Sementara dalam aspek manajemen, PTKI banyak yang telah terakreditasi BAN-PT dengan nilai baik. Perubahan semacam ini merupakan keharusan yang dilakukan oleh sebuah organisasi. ${ }^{1}$ Diantaranya harus ada beberapa indikator perubahan baik bagi sebuah organisasi ialah perubahan sikap, ketrampilan kerja, peran kerja, teknologi, dan startegi. ${ }^{2}$

Perubahan akan terjadi apabila terjalin kerjasama antar pribadi dan rasa memiliki terhadap perguruan tinggi. Tanggung jawab perubahan tersebut tentu harus diemban secara gotong royong oleh seluruh civitas akademika dari pimpinan hingga bawahan. Namun untuk keluar dari convert zone (zona nyaman) bukanlah hal mudah, terlebih dalam suatu organisasi yang sudah mapan.

Sebagaimana pula Rhenald Kasali tegaskan bahwa perubahan organisasi sangat identik dengan tiga hal, yakni: pertama, perubahan membutuhkan waktu, biaya, dan kekuatan. Keberhasilan dalam keluar dari zona nayama perlu kematangan

\footnotetext{
${ }^{1}$ Renald Kasali, Change (Jakarta: Gramedia, 2010). 29

${ }^{2}$ H U Simbolon, R, dan Anisah, 'Pengaruh Perubahan Organisasi Dan Budaya Organisasi Terhadap Kinerja Pegawai. Jurnal Wawasan Manajemen, Volume 1 Nomor 1 ', 1 (2013). 39
} 
berpikir, kepribadian yang teguh, konsep yang jelas, dan sistematis, dilakukan secara bertahap, dan dukungan yang luas. Kedua, perubahan selalu menakutkan dan menimbulkan kepanikan-kepanikan. Namun dengan teknik-teknik komunikasi dan perilaku yang baik, perubahan dapat dikelola menjadi baik. Ketiga, perubahan memerlukan change maker yang dapat mengorganisir arah perubahan organisasi.

Uraian ketiga aspek tersebut menunjukkan bahwa keberadaan komunikasi menjadi sangat krusial dalam mendorong perubahan organisasi. Komunikasi antar personal menjadi salah satu faktor penting mewujudkan visi dan misi organisasi. Oleh karena itu, Utami dalam risetnya menyebutkan bahwa perubahan seringkali perlu dirancang, direkayasa, dan dikelola oleh suatu kepemimpinan yang kuat, visioner, cerdas, dan beorientasi ke depan. ${ }^{3}$

Komunikasi oleh beberapa ahli strategi diyakini sebagai kunci keberhasilan bagi perubahan organisasi. Diantaranya Prabawanti (2008) menyatakan komunikasi yang sering dianggap penting dalam mencapai tujuan organisasi ialah penyebaran informasi. Penerimaan informasi dalam teori komunikasi harus sejalan dan sepaham dengan penyebarannya. Artinya informasi tidak hanya sekedar sebagai sebuah kabar untuk dilaksanakan dan berlalu tetapi juga teriringi sanse of responsibility untuk mewujudkan perubahan dan membangun atmosfer positif dalam berbagai area utama dalam proyek perubahan.

Institut Agama Islam Negeri (IAIN) Pekalongan sebagai perguruan tinggi yang telah lama berdiri tentu telah mengalami berbagai perubahan. Perubahan yang paling mencolok setidaknya terjadi sejak Agustus tahun 2016, yakni ketika dirubahnya status Sekolah Tinggi Agama Islam Negeri (STAIN) menjadi Institut Agama Islam Negeri (IAIN) Pekalongan. Perubahan institusional ini kemudian diiringi oleh penambahan tenaga pendidik dan ahli secara besar-besaran pada awal tahun 2018 yang serentak direkrut oleh pemerintah.

Penambahan anggota civitas akademika di IAIN Pekalongan mencapai jumlah yang fantastis, ialah 75 orang anggota baik dosen dan tendik disusul penambahan berikutnya 6 orang PNS tahap 2 dan 6 orang dosen tetap non PNS. Penambahan yang membludak ini tentu menjadi PR (Pekerjaan Rumah) tersendiri bagi instituti untuk mampu membangun persepsi dan budaya yang sama demi mewujudkan misi institusi. Ketidakmampuan dan ketidak terdukungan lingkungan kepada aparatur untuk memahami dan menyesuaikan budaya baru dan lingkungan kerja baru menjadi kendala terbesar capaian visi dan misi institusi. Sehingga perlunya arahan dan bimbingan pimpinan untuk mampu membangun pola pikir dan pemahaman yang sama.

Anggota baru di IAIN Pekalongan resmi diterima dan bekerja pada 3 Maret 2019. Dalam kurun waktu yang singkat para civitas akademika dituntut untuk bekerjasama dan menyamakan persepsi demi terwujudkan SDM yang berwawasan ke Indonesiaa, memiliki spiritualitas yang baik, berpaham moderat, berkeilmuan tinggi, dan mampu menciptakan generasi mandiri dengan berjiwa entrepreneurship. Salah satu penunjang keberhasilan mewujudukannya ialah tranformasi informasi yang baik melalui komunikasi.

${ }^{3}$ Utami, Setyaningsih S, 'Pengaruh Kepemimpinan Dalam Perubahan Organisasi.', Ekonomi Dan Kewirausahaan, 7 (2007). 124-129 
Maka komunikasi dalam penilitian ini sangat penting dilaksanakan dengan tujuan untuk mengetahui seberapa besar pengaruh komunikasi pemimpin kepada aparatur dalam mewujudkan misi institusi di lingkungan IAIN Pekalongan. Metode yang penulis gunakan dalam peneilitian ini ialah kualitatif lapangan dengan pendekatan studi kasus. Studi kasus yang penulis lakukan ialah intrinsik, penelitian akan fokus pada kegiatan komunikasi organisasi yang dilakukan oleh pemimpin kepada aparatur dilingkungan IAIN Pekalongan. Sedangakan pengumpulan data menggunakan sampling dengan studi analisis datanya ialah holistik. Analisis holistik diperlukan penulis untuk mendiskripsikan secara detail atas pola komunikasi, konteks komunikasi, dan setting di mana komunikasi itu dilakukan. ${ }^{4}$ Sampel penelitian ini diambil melalui wawancara tidak terstruktur kepada pihak pimpinan selaku komunikan dan aparatur sebagai komunikator. Pimpinan yang dimaksudkan ialah para pemangku tertinggi disetiap fakultas baik FUAD (Fakultas Ushuluddin, Aadab, dan Dakwah), FEBI (Fakultas Ekonomi dan Bisnis Islam), FTIK (Fakultas Tadris dan Ilmu Keguruan), dan FASYA (Fakultas Syar'ah).

Paparan diatas mendorong penulis ingin mengetahui sebarapa besar pengaruh komunikasi organisasi pemimpin terhadap kinerja aparatur di IAIN Pekalongan pada masa tahun 2019 hingga 2020?

\section{Hasil dan Pembahasan}

\section{a. Komunikasi Organisasi Pimpinan}

Robbins \& Timothy mengatakan komunikasi harus meliputi baik pemindahan maupun pemahaman makna..$^{5}$ Lebih luas lagi Brent D. Ruben dalam Ami Muhammad menjelaskan komunikasi manusia adalah suatu proses melalui individu dalam hubungannya dengan individu, kelompok, organisasi, dan masyarakat untuk menciptakan, mengirimkan, dan menggunakan informasi dengan maksud mengkoordinasikan lingkungan dan orang lain. ${ }^{6}$ Artinya secara jelas bahwa komunikasi mampu memberikan pengaruh besar baik individu maupun kelompok. Sedangkan dalam komunikasi terjadi proses pemindahan ide dengan maksud merubah sikap, pendapat, dan perilaku apabila komunikasi yang dilakukan komunikatif. Komunikasi komunikatif ialah tidak hanya tahu bahasa yang digunakan, akan tetapi juga mengerti makna dari bahasa yang diucapkan. Respon penting dalam transfer informasi ialah kesediaan komunikan dalam melaksanakan tugas dan bertanggungjawab atas seluruh tanggung jawab yang diemban dalam organisasi.

${ }^{4}$ John W. Creswell, Research Design: Qualitative \& Quantitative Approach (London: SAGE, 2014) <https://www.researchgate.net/profile/RulinawatyKasmad/publication/342229325_Second_Edition_QUALITATIVE_INQUIRY_RESEA RCH_DESIGN_Choosing_Among_Five_Approaches/links/5ee9801992851ce9e7ea3c5f/ Second-Edition-QUALITATIVE-INQUIRY-RESEARCH-DESIGN-Choosing-Among>. 213

${ }^{5}$ Robbins, Stephen P. \& Timothy A. Judge, Perilaku Organisasi, 16th edn (Jakarta: Salemba Humanika). 223

${ }^{6}$ Arni Muhammad, Komunikasi Organisasi, 10th edn (Jakarta: Bumi Aksara, 2009). 93 
Secara fungsional komunikasi organisasi ialah petunjuk dan penafsiran pesan interaksi yang merupakan bagian dari organisasi. Sedangkan secara subjektif (interpretatif) komunikasi organisasi menciptakan proses makna dalam sebuah interaksi. Dua perspektif di atas dapat disimpulkan bahwa komunikasi organisasi tidak hanya sebatas interaksi tetapi perilaku engorganisasian melalui pesan yang disampaikan. ${ }^{7}$ Secara umum komunikasi organisasi dapat dibedakan menjadi dua bagian:

a. Komunikasi formal, merupakan keseluruhan komunikasi terstruktur dan direncanakan serta mendapat persetujuan anggota organisasi.

Bettinghaus (1997) dalam buku Liliweri ada tiga bentuk komunikasi formal:

1) Menuju pada arah vertikal dan horizontal/ lateral

2) Jaringan komunikasi menyersuaikan tusi ( tugas dan fungsinya)

3) Secara formal, alur komuikasi dibatasi oleh kebijakan. ${ }^{8}$

Komunikasi formal terbagi atas dua bagian ialah komunikasi vertikal dan horizontal. Komunikasi vertikal merupakan interaksi dari atas ke bawah atau terstruktur. Sedangkan komunikasi vertikal dari bawah ke atas ialah komunikasi yang menyampaikan informasi dari anggota ke pimpinan organisasi. Komunikasi vertikal berfungsu untuk mengumpulkan informasi penting; memberikan kesempatan kepada para anggota untuk mengemukakan aspirasi dan mengajukan pertanyaan; mendapatkan timbal balik dari bawah; mengemukakan problem pelaksanaan kerja.

Komunikasi horizontal ialah transformasi informasi dari unit kerja yang eselonnya/stratanya sama atau sejajar. Komunikasi horizontal berfungsi untuk mengkoordinasikan aktivitas, berbagi informasi, memecahkan problem dan konflik, mengembangkan kerjasama, dan saling mengerti.

b. Komunikasi informal, ialah komunikasi yang tidak direncakan, alurnya tidak terstruktur, timbul dari interaksi sosial yang biasa dilakukan diantara anggota organisasi lain setiap waktunya. Dikatakan oleh Pace \& Boren bahwa komunikasi informal sama halnya dengan komunikasi intim yang kita miliki dengan orang lain, dalam konteks ini disebut sebagai hubungan antar personal. Pace \& Boren membuat analisis khusus tentang efektivitas hubungan antar personal yaitu:

1) Menjaga toleransi dengan tanpa rasa permusuhan

2) Menunjukkan identitas diri baik antar personal dan organisasi

3) Menyampaikan informasi sejara komperhensif

7 Pace, R. Wayne \& Don F. Faules, Komunikasi Organisasi: Strategi Meningkatkan Kinerja Perusahaan, ed. by Ph. D. Terj: Deddy Mulyana, MA. (Bandung.: Rosda Karya, 2001). 31-33 2011). 295

8 A Alo Liliweri, Komunikasi Antar Personal (Jakarta: Remaja Rosdakarya,

${ }^{9}$ Alo Liliweri. 299 
4) Ikut serta dalam problem solving secara terbuka tanpa menghentikan proses

5) Ikut andil dalam menjaga hubungan personal dan antar personal yang efektif

6) Ikuti serta dalam interaksi sosial informal tanpa mengganggu komunikasi yang efektif. ${ }^{10}$

Sedangkan cara untuk mencapai efektifitas hubungan antar personal menurut Pace \& Boren yaitu:

1) Menyampaikan perasaan secara langsung dengan hangat dan ekspresif

2) Menujukkan peningkatan diri sebagai tanda suatu realita kebenaran individu

3) Menuturkan penjelasan dengan penuh kehangatan, agar respon komunikator relevan dan penuh pengertian

4) Menunjukkan sikap penerimaan yang tulus aik verbal maupun non verbal

5) Menyampaikan pandangan positif dan tidak bersifat menghakimi

6) Berterus terang dalam menyampaikan alasan dengan perkataan yang cermat, jujur, dan membangun.

Dalam interaksi informal, sebuah hubungan antar personal harus bersifat mengalir dan startagis meskipun kadang nampak berubahubah dan bersifat interen dalam diri komunikator. Dalam istilah komunikasi disebut dengan grapevine, ialah sebagai metode interaksi untuk menyampaikan rahasia dengan orang lain yang tidak dapat diperoleh melalui jaringan komunikasi formal. Meski disebut sebagai grapevine, tetap membawa manfaat bagi organisasi. Grapevine memberikan timbal balik kepada pemimpin mengani sentimen karyawan. Selain itu, grapevine membantu pula dalam menterjemahkan arahan pimpinan dengan bahasa yang lebih mudah dimengerti. Komunikasi menjadi instrumen penting dalam menyebarkan berbagai informasi dan intruksi agar dikerjakan oleh anggota organisasi sehingga dapat terwujud sinergitas antar individu. Sinergitas antar individu penting diciptakan. Sebagaimana Mondy dan Premeaux "the coperative action of two or more persons working together to accomplish more than they could working separetly" bahwa kerjasama akan mewujudkan sesuatu yang besar dari pada melakukannya sendiri atau tanpa kerja sama. ${ }^{11}$

Adapun fungsi penting komunikasi organisasi menurut Brent D. Ruben ialah sebagai berikut:

a. Mengkoordinasikan aktivitas individu, kelompok, atau unit-unit lain dalam organisasi

${ }^{10}$ Pace, R. Wayne \& Don F. Faules. 48

${ }^{11}$ Shane R. Mondy, R. Wayne \& Premeaux, Management (New Jersey: Prentice, 1995). 420 
b. Melakukan pembinaan secara menyeluruh kepada anggota organisasi

c. Membuka jalan mediasi dan diplomatika dalam organisasi

d. Menjamin adanya arus timbal balik (two way flow informastion) antara organisasi dan lingkungan ekternal organisasi.

Selain fungsi, komunikasi organisasi juga memiliki tujuan utama ialah :

a. Sebagai Tindakan Organisasi

Untuk mengkoordinasikan sebagian atau seluruh tugas dan fungsi organisasi demi terlaksananya visi dan misi. Organisasi tanpa komunikasi dan koordinasi sama dengan organisasi yang menampilkan aspek individual dan bukan menggambarkan aspek kerjasama kelompok.

b. Membagi Informasi (Informasi Sharing)

Komunikasi mengarahkan manusia dan aktivitas dalam organisasi, salah satu tujuan penting komunikasi adalah menghubungkan seluruh aparatur organisasi demi tercapainya tujuan organisasi. Fungsi penyampaian informasi untuk membagi kemudian menjelaskan tujuan organisasi, dari suatu tugas, usaha untuk mencapai tugas, dan pengambilan keputusan.

c. Menampilkan perasaan dan emosi

Dalam organisasi terdiri atas kelompok manusia yang memiliki keterhubungan kerja. Setiap dari mereka mempunyai kebutuhan dan keinginan, perasaan, dan emosi yang harus diungkapkan. Maka dalam organisasi juga bertujuan untuk mengkoordinasikan dan mengorganisir ekspresi atau emosi yang berbeda agar tetap se-visi dan misi demi mweujudkan tujuan organisasi.

\section{b. Pemimpin dan Kinerja Aparatur di IAIN Pekalongan}

Sentralnya peran komunikasi dalam organisasi menunjukkan bahwa suatu tujuan besar ditentukan oleh bagaimana kelancaran dan ketercapaian tujuan komunikasi. Seorang pemimpin dapat diukur kualitas atau kualifikasi kepemimpinannya dari proses komunikasi. sebagai berikut :

Secara umum seorang pemimpin memiliki beberapa karakteristik

a. Tanggung Jawab yang seimbang

b. Model peranan yang positif

c. Memiliki ketrampilan komunikasi yang baik

d. Memiliki pengaruh yang positif

e. Memiliki kemampuan untuk menyakinkan orang lain. ${ }^{12}$

Disamping memiliki karakteristik sebagaimana telah disebutkan diatas, Bennis dalam buku Fandy Tjiptono, berjudul Manajemen Pemasaran dan Analisa

12 F. Tjiptono, Manajemen Pemasaran Dan Analisa Perilaku Konsumen. (Yogyakarta: BPFE, 2001). 83 
Perilaku Konsumen menjelaskan bahwa seorang pemimpin juga harus memainkan peranan penting dalam tiga hal berikut :

1) Mengatasi penolakan terhadap perubahan

2) Menjadi perantara bagi kebutuhan kelompok-kelompok didalam dan di luar organisasi

3) Membentuk kerangka etis yang menjadi dasar operasi setiap karyawan dan perusahaan secara keseluruhan.

Sedangkan tujuan dan keberhasilan kinerja seluruh lapisan baik pemimpin maupun aparatur dapat terukur dengan menerapkan komunikasi efektif. Oleh karena itu secara aksiomatik organisasi akan berhasil apabila pesan komunikasi disampaikan dengan baik dan benar.

Ada beberapa fungsi pesan komunikasi organisasi yang berhubungan dengan tugas-tugas kemanusiaan dan pembaharuan, yaitu:

a. Pesan tugas, yaitu pesan yang berkaitan dengan pelaksanaan tugas-tugas organisasi oleh aparatur. Pesan mencakup pemberian informasi kepada bawahan untuk melakukan tugas secara efisien, seperti pemberian latihan, orientasi, penentuan tujuan, produktivitas dan lainlain.

b. Pesan pemeliharaan, yaitu pesan yang berkenaan dengan kebijakan dan pengaturan organisasi. Pesan ini mencakup perintah, ketentuan, prosedur, aturan dan kontrol yang diperlukan untuk mempermudah gerakan organisasi DEMI mencapai output sistem.

c. Pesan kemanusiaan, yaitu diarahkan kepada nggota organisasi dengan mempertimbangkan sikap dan moral. Pesan ini berkenaan dengan hubungan interpersonal, konsep diri perasaan, dan moral. Yang termasuk dalam kategori pesan ini adalah penghargaan terhadap hasil yang dicapai, penyelesaian konflik antara individu atau kelompok aktivitas informal dan bimbingan.

d. Pesan pembaharuan, yaitu pesan yang menjadikan organisasi mampu menyesuaikan diri dengan perubahan-perubahan yang terjadi dalam lingkungannya. Untuk itu suatu organisasi membuat rencana-rencana baru, aktivitas-aktivitas baru, program-program baru, proyek-proyek baru, dan saran-saran baru. ${ }^{13}$

Sifat terpenting pesan komunikasi organisasi ialah penciptaan pesan, penafsiran, dan penanganan kegiatan anggota organisasi serta makna yang terkandung. Makna yang dimaksudkan bergantung pada konsepsi seseorang tentang organisasi. ${ }^{14}$ Pesan-pesan komunikasi pimpinan di tingkat Institut Agama Islam Negeri Pekalongan terhadap seluruh aparatur baru ini dimaksudkan untuk mendorong terbentuknya satu ideologi yang sama demi terwujudnya visi misi institusi.

Ideologi berperan penting dalam mendorong aparatur lebih mengembangkan diri. Rekrutmen Pegawai Negeri Sipil/ aparatur tahun 2018

\footnotetext{
${ }^{13}$ Arni Muhammad. 99

${ }^{14}$ Pace, R. Wayne \& Don F. Faules. 34
} 
oleh negara memberikan wajah baru bagi setiap kampus, salah satunya IAIN Pekalongan. IAIN Pekalongan sejak pertama berdiri tahun 1997 barulah tahun 2018 memperoleh 78 orang aparatur baru, yang rekrutmennya melalui dua tahap. Adapun rincian aparatur baru di lingkungan IAIN Pekalongan ialah:

\begin{tabular}{|c|l|l|}
\hline No & Nama Fakultas & $\begin{array}{l}\text { Jumlah } \\
\text { Aparatur }\end{array}$ \\
\hline 1 & FEBI (Fakultas Ekonomi dan Bisnis Islam) & 9 orang \\
\hline 2. & FTIK (Fakultas Tadris dan Ilmu Keguruan) & 12 orang \\
\hline 3. & FUAD (Fakultas Ushuluddin Adab dan Dakwah) & 11 orang \\
\hline 4. & FASYA (Fakultas Syari'ah) & 7 orang \\
\hline 5. & Pascasarjana & 2 orang \\
\hline 6. & $\begin{array}{l}\text { LP2M (Lembaga penelitian dan Pengabdian } \\
\text { Masyarakat) }\end{array}$ & 6 orang \\
\hline 7. & LPM (Lembaga Penjaminan Mutu) & 1 orang \\
\hline 8. & Satuan Pengawas Internal & 3 orang \\
\hline 9. & Unit Pengembangan Bahasa & 3 orang \\
\hline 10. & Perpustakaan & 3 orang \\
\hline 11. & $\begin{array}{l}\text { UTIPD (Unit Teknologi Informasi dan Pangkalan } \\
\text { Data) }\end{array}$ & 3 orang \\
\hline 12. & Ma’had Al-Jami'ah & 4 orang \\
\hline 13. & Bagian Perencanaan & 1 orang \\
\hline 14. & Bagian Keuangan dan BMN & orang \\
\hline 15. & Bagian Akademik, Kemahasiswaan, dan Alumni \\
\hline 16. & $\begin{array}{l}\text { Bagian orgnaisasi, kepegawaian. Dan penyusunan } \\
\text { peraturan }\end{array}$ & 2 orang \\
\hline & \multicolumn{1}{|l|}{ Jumlah orang } \\
\hline
\end{tabular}

Tabel 1.1

Data Aparatur Baru IAIN Pekalongan tahun 2019

Banyaknya aparatur /PNS baik dosen dan tenaga kependidikan di lingkungan IAIN tentu memberi pengaruh besar. Harapannya pengaruh baik untuk kemajuan dan pengembangan IAIN Pekalongan ke depan.

Berdasarkan data resmi pada website Siiman milik IAIN Pekalongan, jumlah aparatur mencapai 577 orang. 
Grafik Pegawai

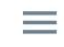

Institut Agama Islam Negeri Pekalongan

Pegawai dan Dosen PNS: 257

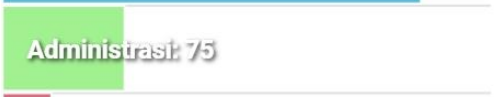

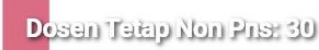

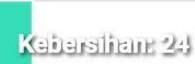

Saljeane 24

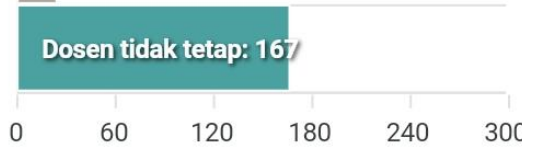

Pegawai dan Dosen PNS Administrasi

Dosen Tetap Non Pns Kebersihan

Satpam Dosen tidak tetap

Tabel. 1.2.

\section{Grafik Pegawai dan Aparatur di IAIN Pekalongan}

Pimpinan di tingkat perguruan tinggi dipegang oleh Rektor dan dibantu wakil rektor serta Kabiro (Ketua Bidang Organisasi). Sedangkan di tingkat Fakultas untuk menjalankan roda organisasi Rektor dibantu oleh Dekan. Dekan dibantu oleh Wakil Dekan dan Kabag, sedangkan ditingkat lembaga dibantu oleh Ketua Lembaga dan jajarannya.

IAIN Pekalongan sering melaksanakan pertemuan-pertemuan baik resmi maupun tidak resmi dari tingkat atas (pimpinan) maupun tingkat bawah. Pertemuan resmi rapat koordinasi tingkat pimpinan, rapat awal perkuliahan, dan rapat yang lain. Sedangkan pertemuan tidak resmi misalnya, pertemuan olahraga, pentas seni mahasiswa, diskusi rutin, dan kegiatan lainnya.

Kemajuan kampus akan terwujud dari kinerja yang bagus baik secara kuantitatif maupun kualitatif. Menurut Mangkunegara (2009) dalam Norianggono, dkk., 2014), menjelaskan capaian hasil kerja aparatur secara komultaif terbentuk atas kinerja yang baik. Menurut Tohardi dalam Indrajaya, A. \& Adnyani, A, bahwa faktor pendukung yang mempengaruhi kinerja karyawan adalah pendidikan, kedisiplinan, etika kerja yang baik, keterampilan, pemahaman 
atas budaya kerja; manajemen diri, kesempatan berprestasi, tingkat penghasilan, beban pekerjaan, teknologi, dan lingkungan kerja yang baik. ${ }^{15}$

Kriteria disiplin kerja yang baik adalah apabila;

a. Patuh terhadap aturan, seperti datang tepat waktu, tertib, dan teratur. Secara langsung hal ini akan pengaruh terhadap hasil kinerja.

b. Rapi dalam berbusana. Mengenakan pakaian rapi juga didukung dengan seragam yang sesuai dengan seragam yang telah ditentukan. Hal ini bertujuan untuk meningkatkan kepercayaan diri pada karyawan.

c. Mampu menggunakan perlengkapan kerja dengan baik. ${ }^{16}$

Pelaksanaan kinerja aparatur tidak lantas tidak memiliki kualifikasi penilaian. Dalam Peraturan Pemerintah (PP) Nomor 30 Tahun 2019 tentang Penialaian Kinerja Pegawai Sipil (PNS). Secara objektif penilaian kinerja aparatur negara ialah dengan sistem prestasi dan sistem karir

Penilaian Kinerja PNS berdasarkan pasal 4 Peraturan Pemerintah (PP) Nomor 30 Tahun 2019 dilakukan berdasarkan prinsip:
a. Objektif;
b. Terukur
c. Akuntabel;
d. Partisipatif; dan
e. Transparan.

Sedangkan Sistem Manajemen Kinerja PNS dinilai Peraturan Pemerintah (PP) Nomor 30 Tahun 2019 dilaksanakan terdiri atas:

a. perencanaan kinerja;

b. pelaksanaan, pemantauan kinerja, dan pembinaan kinerja;

c. penilaian kinerja;

d. tindak lanjut; dan

e. Sistem Informasi Kinerja PNS.

Dalam Peraturan Pemerintah (PP) Nomor 30 Tahun 2019 tentang Penilaian Kinerja Pegawai Negeri Sipil (PNS) Perencanaan Kinerja terdiri atas penyusunan dan penetapan SKP (Sasaran Kinerja Pegawai) dengan memperhatikan Perilaku Kerja. Proses penyusunan SKP dilakukan dengan memperhatikan:

a. perencanaan strategis Instansi Pemerintah;

b. perjanjian kinerja;

c. organisasi dan tata kerja;

${ }^{15}$ A. Indrajaya, A. \& Adnyani, 'Pengaruh Budaya Organisasi, Komunikasi Dan Lingkungan Kerja Terhadap Produktivitas Kerja Karyawan CV Hitakara Denpasar. EJurnal Manajemen', E-Jurnal Manajemen, 2 (2013) <https://ojs.unud.ac.id/index.php/Manajemen/article/view/4770>. 103

16 Hasibuan, S. P. Malayu, Manajemen Sumber Daya Manusia (Jakarta: Bumi Aksara, 2003). 81 

d. uraian jabatan; dan/atau
e. SKP atasan langsung.

\section{c. Komunikasi Organisasi Pemimpin terhadap Aparatur}

Dalam komunikasi yang sempurna, suatu pemikiran akan dikirimkan kepada penerima sehingga pesan dapat dipahami maksud tujuan sesuai dengan gambaran mental yang sama dengan dimaksudkan oleh si pengirim. KomuniV kasi yang terjalin antara pimpinan dan aparatur di IAIN Pekalongan berjalan dengan harmonis.

Harmonitas yang dibangun oleh pimpinan terhadap aparatur baru tahun 2019, sebagaimana hasil wawancara lapangan yang dilaksanakan peneliti menunjukkan komunikasi yang dipraktikan dilingkungan IAIN Pekalongan menganut asas kekeluargaan dan kebudayaan. Kekeluargaan yang dimaksudkan ialah dengan mempraktikkan unsur Asih, Asah, dan Asuh. Adapun budaya yang dimaksudkan ialah tetap mengedepankan tata krama dan unggah ungguh dalam berbahasa maupun berprilaku.

\section{Prinsip Asih}

Asih merupakan cerminan kasih sayang antara satu dengan lainnya yang akan menimbulkan rasa kewasapadaan diri agar terhindar dari suatu hal yang dapat mengganggu harmonitas institusi. Hal ini terwujud dibeberapa kegiatan baik formal maupun non formal dalam interaksi sehari-hari.

Kegiatan formal seperti trining leadership, FGD (Forum Group Discussion), workshop, seminar dan sebaginya. Komunikasi terjalin dengan pembinaan intens dari pemimpin kepada aparatur dibeberapa kegiatan tersebut. Komunikasi yang terwujud dalam kegiatan-kegiatan tersebut, didorong oleh rasa kasih sayang pimpinan kepada aparatur agar memiliki kemampuan kompetitif baik di dalam maupun luar instansi.

Adapun secara non formal prinsip asih terwujud pada pembinaan spirtual misal, setelah sholat berjamaah dhuhur dan asyar ada tausiyah, mengirimkan do'a bagi aparatur atau keluarga aparatur yang sakit, meninggal, maupun tertimpa musibah yang lain dalam acara istghasah, mewujudkan rasa kasih sayang dalam kekompakan saat terlibat dalam kegiatan outbound, menjenguk dikala salah satu teman sakit, dan asih juga terwujud dalam interaksi melalui pelaksanaan tugas sehari-hari di kantor. Seperti membantu memahamkan jika ada pegawai yang kurang paham dengan pekerjaannya, saling bekerja sama untuk menyelesaikan pekerjaan yang bersifat team.

Wujud kepedulian pemimpin dalam menyamakan persepsi dan pola pikir serta pemahaman tentang visi misi organisasi kepada aparatur baru bertujuan untuk membangun organisasi lebih baik dan maju. Komunikasi didasari atas rasa kasih sayang mampu mendorong seseorang saling memupuk rasa peduli dan saling mengerti. ${ }^{17}$ Kepedulian antar sesama diajarkan oleh Islam,

${ }^{17}$ George Ritzer, Sosiologi Ilmu Pengetahuan Berparadigma Ganda (Jakarta: Grafindo Persada, 2002). 74 
sebagaimana hadist riwayat Ahmad, al Bukhari, dan Muslim bahwa, "Seorang muslim itu adalah saudara muslim yang lain. Oleb sebab itu, jangan menzalimi, jangan meremebkan nya, dan jangan menyakitinya."18 Hadits ini menegaskan bahwa antar orang harus bersaudara dan saling memberikan rasa nyaman dengan memupuk rasa kasih sayang agar tujuan komunikasi tercapai. Tujuan utama komunikasi sebagaimana Alo Liliweri menjelaskan bahwa untuk membangun atau menciptakan pemahaman atau pengertian yang sama. ${ }^{19}$

Seluruh anggota aparatur diharapkan mampu memupuk persaudaraan sebagaimana perintah Nabi dalam hadist di atas. Meski dalam sebuah organisasi terjalin kondisi saling berkompetisi tetapi pun harus dalam situasi yang harmonis dan dengan cara yan sehat.

Pembinaan dalam suatu organisasi dilakasanakan untuk menciptakan karsa kerja. Artinya mendorong setiap individu (pegawai) untuk sama-sama berkehendak mewujudkan visi dan misi dan memajukkan institusi. ${ }^{20}$ Sebagaimana dalam keilmuan psikilogi, pola asih penting diwujudkan bagi setiap individu agar menimbulkan rasa aman, rasa dihargai, diperhatikan, memiliki pengalaman baru, sehingga terwujud rasa tanggung jawab untuk mengemban amanat negara di IAIN.

\section{Prinsip Asah}

Asah merupakan usaha untuk menghadapi tantangan dan peluang baik secara individu maupu gotong royong dapat pula disebut pembekalan diri. Hal ini tercermin dalam beberapa kegiatan baik formal maunpun non formal. Usahausaha pimpinan di lingkungan IAIN Pekalongan dalam memupuk kemampuan aparatur baru ialah dengan memberikan pembekalan diri, pendampingan intesif, sharing pengalaman, dan pengetahuan sesuai dengan kebutuhan.

Pembekalan diri dapat berbentuk pendampingan baik secara langsung maupun tidak langsung dari aparatur senior ke aparatur junior. Teraktualisasikan dalam kepanitiaan, senior mengajarkan cara keprotokoleran yang baik dan benar kepada aparatur baru dalam mengadakan kegaitan, diadakannya workshop bagi dosen dan pegawai untuk memberikan bekal bagi individu aparatur dalam melaksanakan tugasnya. pendampingan dan sharing dalam melaksanaan pengajaran, melayani, dan menyelesaikan tugas-tugas, serta kegiatan yang lain. Kinerja individu merupakan dasar bagi kinerja organisasi, ${ }^{21}$ oleh karena itulah prinsip asah ini menjadi sangat urgen. Sebab mengingat IAIN Pekalongan baru pertama kali memperoleh ASN (Aparatur Sipil Negara) dengan jumlah sangat banyak dan berasal dari berbagai latar belakang budaya dan wilayah.

${ }^{18}$ Al- Bukhari Abu Abdullah Muhammad bin Ismail, Ensiklopedia Hadits 2; Shahih Al-Bukhari 2 (Jakarta: Penerbit Alhmahira, 2012). 249

${ }^{19}$ Alo Liliwer, Komunikasi Verbal Dan Non Verbal (Bandung: Citra Aditya Bakti, 1997). 14

${ }^{20}$ Djoko Widagdhi, Ilmu Budaya Dasar, 9th edn (Jakarta: Bumi Aksara, 2004). 20

${ }^{21}$ James H. Donnelly Jr. Gibson, James L., John M. Ivancevich, Organizational Behavior, Structure, Processes, 7th edn (USA Boston: Richard D. Irwan, Inc., 1991). 11 
Kebersamaanpun harus dipupuk dengan rasa saling menghormati, kemudian menjadi landasan pokok tindakan dalam berbagai keterlibatannya yang pada akhrinya akan menumbuhkan sikap komitmen dan tanggung jawab diri dalam setiap individu aparatur.

Pengaruh lingkungan dan individu menurut para psikologi lebih efektif dalam merubah perilaku individu. Para pakar psikoloh sosial mengatakan perubahan perilaku individu yang dipengaruhi oleh orang lain dan kelompok diantaranya konformitas ialah ada indikasi mengubah keyakinan atau perilaku seseorang agar sesuai dengan tujuan baik individu maupun orgnaisasi. ${ }^{22}$ Pembinaan dan pendampingan aparatur yang intens dilakukan pada empat fakultas dan pihak institut. Kegiatan ini dapat berupa pelatihan, workshop, outbound, family gathering, olahraga jalan sehat, sepeda santai, dies natalis, dan yang lain.

Prinsip asah ini jika konsisten terlaksana dapat meningkatkan kinerja aparatur. Apalagi menurut Cumming bahwa kinerja aparatur tidak dapat muncul dengan sendirinya melainkan perlu dibentuk. ${ }^{23}$

Salah satu contoh yaitu, disetiap kegiatan tidak lupa dibuka dengan do'a. Sebagaimana pada beberapa fakultas memiliki tradisi berbeda dalam melaksanakan prinsip asih ini. Diantaranya FUAD, adanya Rabu berkah budaya siraman kalbu dengan khotmil Qur'an seminggu sekali setiap hari rabu, membudayakan membaca asmaul husna pada kegiatan-kegiatan rapat, webinar, perkuliahan, dan kegiatan lainnya. Pembekalan diri tidak selalu terwujud dalam bentuk pendampingan kepanitiaan, melainkan pula spiritual baik istgosah maupun dzikir bersama.

\section{Prinsip Asuh}

Secara harfiah prinsip asuh teraktualisasikan dalam kehidupan sehari-hari di lingkungan IAIN dari pemimpin hingga aparatur dibawahnya. Ialah pada beberapa kegiatan dalam kepanitian, rapat pembinaan pegawai, dan rapat kerja tahunan. Baik komunikasi secara formal maupun non formal terjalin dengan baik. Baik antar pimpinan, pimpinan ke aparatur dibawahnya, maupun antar aparatur yang lain.

Komunikasi pimpinan kepada aparatur dibawahnya tercermin dalam kegiatan penjaminan mutu atau kwalitas diri. Dengan selalu melihat dan menindak lanjuti nilai IKAD (Indek Kinerja Akademik Dosen) bagi dosen serta SKP (Sasaran Kinerja Pegawai) bagi pegawai. Memberikan pelatihan berupa workshop dan pelatihan untuk menindak lanjuti atas kinerja dan kwalitas diri baik dosen maupun pegawai.

Reward diberikan oleh pimpinan di masing-masing fakultas untuk memberikan support terhadap kinerja para aparaturnya. Misalnya ditingkat Institut setiap tahun penghargaan diberikan oleh Rektor kepada aparaturnya yang

\footnotetext{
${ }^{22}$ Letita Anne Peplau \& Dvud O. Sears. Taylor, Shelley E., Psikologi Sosial (Jakarta: Salemba Humanika, 2009). 535

${ }^{23}$ Thomas G. Cummings \& Christoper G. Worly, Organizational Develpoment and Change., 8th edn (Thomson Corporation., 2005). 157
} 
memiliki nilai IKAD tertinggi dan kesesuaian SKP dengan realitas kinerja. Selain itu punishmant pun diberikan kepada dosen dan pegawai yang melanggar aturan, misalnya tidak berangkat tepat waktu dan tidak melaksanakan tugas sesuai dengan tusi-nya.

Reward dan punishment diberlakukan demi mewujudkan kedisiplinan dan ketercapaian visi-misi kampus. Komunikasi oragnisasi semacam ini menurut Handoko dapat memperkuat motivasi untuk memacu diri agar mencapai prestasi dan atau memberi lebih banyak kepada aparatur agar tetap berprestasi. Terutamanya dalam mewujudkan visi, misi, dan tujuan organisasi. ${ }^{24}$

Selain reward dan punishment pemimpin dimasing-masing fakultas juga memiliki langkah dan trik masing-masing dalam upaya membangun sense of belonging dan menumbuhkan rasa saling peduli serta memperhatikan aparatur bawahannya. Misalnya di FUAD (Fakultas Ushuluddin, Adab, dan Dakwah) para pimpinan kerap mengajak bawahannya untuk melakukan olahraga seperti bulu tangkis dan jogging bersama. Selain untuk membangun kebugara tubuh, juga untuk menumbuhkan kedekatan memupuk rasa saling peduli satu dengan yang lain. Kegiatan-kegiatan tersebut menunjukkan bahwa harmonitas organisasi yang terbangun dari nilai sosial dapat mengintegrasikan berbagai kepentingan baik pekerjaan individu maupun kelompok, sehingga terwujud lingkungan kerja yang nyaman.

Semangat kebersamaan yang dipupuk antara pimpinan dan bawahan terbukti mampu meningkatkan semangat dan loyalitas kinerja. Berdasarkan hasil survei pelayanan tahun 2020 yang dilaksanakan oleh pihak Fakultas Ushuluddin, Adab, dan Dakwah kepada stake holder menujukkan kurva pelayanan naik hingga $35 \%$. artinya ada perbaikkan secara dignifikan atas datangnya SDM baru di lingkungan FUAD. Dan tentu hal ini sangat berkaitan erat dengan terjalinnya komunikasi organisasi yang baik dari pimpinan kepada bawahannya pun sebaliknya. Selain itu melalui semangat asuh ini, setiap orang akan berada dalam perasaan yang bebas dari ketidakpastian, ketakutan, keragu-raguan, keresahan dan kecemasan. Sehingga tujuan organisasi akan mudah dicapai bersama.

Ketiga prinsip tersebut tidak hanya terwujud didimensi perpaduan (harmonizing) dan penyatuan (integrating) tetapi juga dimensi perubahan (transforming) di lingkungan kerja. Dalam sistem kepemimpinan yang demikian kepentingan pribadi cenderung lebih ditempatkan di bawah kepentingan umum atau golongan. Oleh karena itu, ketiga prinsip kekeluargaan ini selalu dijaga oleh pimpinan dengan tujuan agar setiap keputusan yang diambil tidak mendominasi proses pengambilan keputusan yang bersifat sewenang-wenang untuk memenuhi kepentingan sendiri.

Sebaliknya aparatur diharapkan juga harus menjaga komunikasi baik secara formal maupun non formal agar tidak timbul rasa memaksakan kehendak sendiri. Dalam konteks itu, dijelaskan oleh (George Ritzer, 1983) dalam simposium Haryo S. Martodirejo, dkk. bahwa seorang pemimpin yang menjiwai semangat prinsip asah, asih, dan asuh akan berada didalam atau disekitar center of

${ }^{24}$ H.T. Handoko, Manajemen Personalia Dan Sumber Daya, 2nd edn (Yogyakarta: BPFE, 2013). 82 
the network system dan tidak menempatkan massa berada di pinggiran (peripheral zone of the network system) sebagaimana konsep kepemimpinan yang sering dijumpai dalam perspektif sosiologi. ${ }^{25}$

Hasil wawancara yang dilakukan oleh peneliti kepada beberapa informan, ialah terdiri dari pimpinan ditingkat institut, fakultas, hingga pegawai ketiga budaya komunikasi organisasi di IAIN Pekalongan tersebut menunjukkan adanya keterikatan emosional dalam setiap kinerja. Emosional kasih sayang, kepedulian, dan kompetitif mampu mendorong kinerja pegawai baru lebih efektif dan menuai hasil nyata.

\section{Kesimpulan}

Tahun 2019 menjadi momen bersejarah Institut Agama Islam Negeri (IAIN) Pekalongan, karena memperoleh tambahan aparatur terbanyak sepanjang sejarah berdirinya kampus tersebut, ialah 78 aparatur. Banyaknya penambahan aparatur ini mengakibatkan para pimpinan harus bekerja esktra dalam membimbing dan menyamakan persepsi agar tujuan organisasi tercapai. Oleh karena itu, penelitian ini dilakukan untuk mengetahui strategi apa yang digunakan para pemimpin sehingga semua aparatur baru, mudah memahami setiap tusi (tugas institusinya) dan budaya kerja organisasi di lingkungan IAIN Pekalongan.

Penelitian ini memperoleh hasil bahwa para pimpinan melakukan komunikasi organisasinya dengan prinsip kebudayaan. Prinsip kebudayaan ini mencakup tiga aspek ialah prinsip asah, asih, dan asuh. Ketiga prinsip ini nampak disetiap kegiatan-kegiatan formal maupun non formal, diantaranya workshop, Trining, FGD, seminar, istighosah, autbond, dies natalis, dan lainnya. Prinsip kekeluargaan terealisasi dalam interaksi sehari-hari baik dalam kantor maupun diluar kantor. Komunikasi organisasinya terjalin secara harmonis dengan disandarkan pada kode etik guyup rukun. Etika guyup rukun nampak pada saat bertutur ria dalam memberikan masukan membangun, baik dari pimpinan maupun antar aparatur. Para pimpinan juga selalu menerapkan emosi kasih sayang, kepedulian, dan empati sehingga mendorong kinerja pegawai baru lebih efektif dan menuai hasil nyata.

\section{Saran}

Pada penelitian sebelumnya terhadap penelitian penulis, dapat disarankan sebagai masukan yang berkaitan dengan komunikasi organisasi dalam lingkungan institusi negeri maupun suwasta bahwa;

1. Diharapkan setiap lembaga institusi mampu memberikan suasana komunikasi organisasi yang efektif dan nyaman terhadap anggota-anggota baru. Sehingga tujuan organisasi mudah diwujudkan dan dapat meminimalisir noise dalam berkomunikasi di lingkungan kerja.

2. Komunikasi dalam setiap kelompok/ organisasi selalu berkaitan erta dengan budaya kerja. Oleh sebab itu, diharapkan pesan dan cara/metode komunikasi

${ }^{25}$ Haryo S. dkk. Matodirejo, "Revitalisasi Silih Asah, Silih Asih, Silih Asuh Dalam Kepemimpinan Partisipatif Masyarakat Sunda Perkotaan: Kasus Penaggulangan Kemiskinan Di Kota Bandung.', Antropologi Indonesia, 2001. 
harus luwes dengan menyesuaikan komunikan dan budaya bertutur di wilayah tersebut. Agar kenyamanan interaksi dan emosionalitas diri dalam setiap individu mudah termenej.

3. Budaya komunikasi organisasi yang baik akan membangun terwujudnya komunitas yang baik, sehingga tujuan organisasi mudah dicapai. Maka diharapkan, setiap pimpinan didalam organisasi, harus mampu melaksanakan komunikasi yang baik dan efektif. 


\section{Daftar Pustaka}

Renald Kasali, Change (Jakarta: Gramedia, 2010).

H U Simbolon, R, dan Anisah, 'Pengaruh Perubahan Organisasi Dan Budaya Organisasi Terhadap Kinerja Pegawai. Jurnal Wawasan Manajemen, Volume 1 Nomor 1', 1 (2013).

Utami, Setyaningsih S, 'Pengaruh Kepemimpinan Dalam Perubahan Organisasi.', Ekonomi Dan Kewirausahaan, 7 (2007).

John W. Creswell, Research Design: Qualitative \& Quantitative Approach (London: SAGE, 2014) <https://www.researchgate.net/profile/RulinawatyKasmad/publication/342229325_Second_Edition_QUALITATIVE_INQ UIRY_RESEARCH_DESIGN_Choosing_Among_Five_Approaches/link s/5ee9801992851ce9e7ea3c5f/Second-Edition-QUALITATIVEINQUIRY-RESEARCH-DESIGN-Choosing-Among>.

Robbins, Stephen P. \& Timothy A. Judge, Perilaku Organisasi, 16th edn (Jakarta: Salemba Humanika).

Arni Muhammad, Komunikasi Organisasi, 10th edn (Jakarta: Bumi Aksara, 2009).

Pace, R. Wayne \& Don F. Faules, Komunikasi Organisasi: Strategi Meningkatkan Kinerja Perusahaan, ed. by Ph. D. Terj: Deddy Mulyana, MA. (Bandung.: Rosda Karya, 2001).

Shane R. Mondy, R. Wayne \& Premeaux, Management (New Jersey: Prentice, 1995).

F. Tjiptono, Manajemen Pemasaran Dan Analisa Perilaku Konsumen. (Yogyakarta: BPFE, 2001).

A. Indrajaya, A. \& Adnyani, 'Pengaruh Budaya Organisasi, Komunikasi Dan Lingkungan Kerja Terhadap Produktivitas Kerja Karyawan CV Hitakara Denpasar. E-Jurnal Manajemen', E-Jurnal Manajemen, 2 (2013) $<$ https://ojs.unud.ac.id/index.php/Manajemen/article/view/4770>.

Hasibuan, S. P. Malayu, Manajemen Sumber Daya Manusia (Jakarta: Bumi Aksara, 2003).

George Ritzer, Sosiologi Ilmu Pengetahuan Berparadigma Ganda (Jakarta: Grafindo Persada, 2002).

Al- Bukhari Abu Abdullah Muhammad bin Ismail, Ensiklopedia Hadits 2; Shahih AlBukhari 2 (Jakarta: Penerbit Alhmahira, 2012).

Alo Liliwer, Komunikasi Verbal Dan Non Verbal (Bandung: Citra Aditya Bakti, 1997).

Djoko Widagdhi, Ilmu Budaya Dasar, 9th edn (Jakarta: Bumi Aksara, 2004).

James H. Donnelly Jr. Gibson, James L., John M. Ivancevich, Organizational Behavior, Structure, Processes, 7th edn (USA Boston: Richard D. Irwan, Inc., 1991).

Letita Anne Peplau \& Dvud O. Sears. Taylor, Shelley E., Psikologi Sosial (Jakarta: Salemba Humanika, 2009).

Thomas G. Cummings \& Christoper G. Worly, Organizational Develpoment and Change., 8th edn (Thomson Corporation., 2005).

H.T. Handoko, Manajemen Personalia Dan Sumber Daya, 2nd edn (Yogyakarta: BPFE, 2013).

Haryo S. dkk. Matodirejo, “Revitalisasi Silih Asah, Silih Asih, Silih Asuh Dalam Kepemimpinan Partisipatif Masyarakat Sunda Perkotaan: Kasus Penaggulangan Kemiskinan Di Kota Bandung.', Antropologi Indonesia, 2001. 